\title{
COLLEGE ACADEMIC FREEDOM IN THE DIGITAL DISRUPTION ERA
}

\author{
Heriyanto \\ Sekolah Tinggi Agama Buddha Negeri Sriwijaya Tangerang Banten \\ heriyanto@stabn-sriwijaya.ac.id
}

\begin{abstract}
The urgency of college academic freedom is to freely seek knowledge, freely to develop knowledge, freely to express the work and to publish scientific papers, and freely to disseminate knowledge to the welfare of society by not abandoning scientific values and academic value. How does academic freedom in the digital disruption era become a separate issue in this study. This study focuses on the implementation of college academic freedom in the digital era. The results of the study are expected to provide a description and to describe the implementation academic freedom in the digital age. This research is library research, this study uses technical analysis of discourse synthesis, taking into account elements of text, context, and discourse. The synthesis is a continuation of the analysis process in an attempt to reconstruct text and context, using comparison of issues and facts in order to explain the implementation of academic freedom in the digital age. Past research, cases, and data obtained from the internet have become an important element in fulfilling the textual subtance and context of academic freedom in the digital age. The results of the study provide an overview of the implementation of college academic freedom in the era of digital disruption. Academic freedom in the era of digital disruption focuses on: 1) Adoption of digital technology in deepening, developing, and disseminating knowledge, 2) Creating new innovations in the implementation of Tridharma College, 3) Keeping scientific values, be professional, and responsible values, 4) Upholding the ethics and morality, 5) Commitment in implementing the management, regulation and policies that has been set, and 6) Creating efficiency, effectiveness, and upgrading the college services.
\end{abstract}

Keywords: Academic Freedom, Digital Disruption, College.

\section{A. Pendahuluan}

Perkembangan teknologi informasi dan komunikasi yang begitu cepat membawa perubahan besar pada berbagai aspek kehidupan masyarakat. Terciptanya berbagai produk dan aplikasi teknologi berdampak pada pergeseran peradaban manusia menuju dan tersentral dalam digitalisasi. Teknologi digital mewajibkan restrukturisasi berbagai jenis proses bisnis dan manajemen lembaga, organisasi, dan institusi baik negeri maupun swasta. Tidak terkecuali pada perguruan tinggi, era digital memaksa adaptasi besarbesaran di mana seluruh komponen dan proses pendidikan harus menerapkan, memanfaatkan, dan terintegrasi melalui teknologi digital. Ketika sekelompok masyarakat menyatakan terjadinya gangguan, akan lebih tepat dinyatakan dengan terjadinya kemajuan dan perkembangan teknologi digital. Kemajuan dan perkembangan teknologi digital membawa terciptanya 
keadaan disrupsi pada perguruan tinggi dalam menciptakan nilai (value) dari bisnis utama yang dijalankan, dalam hal ini jasa pendidikan yang dilakukan. Disrupsi digital terjadi pada target pasar, business core, interaksi sosial, dan yang lebih umum terjadi pada pemahaman dan pemikiran seluruh Sumber Daya Manusia (SDM) dalam perguruan tinggi.

Disrupsi digital terjadi pada seluruh aspek perguruan tinggi, pada individu civitas akademika, proses administrasi dan pembelajaran, fasilitas, sarana dan prasarana, penelitian dan pengabdian kepada masyarakat, serta cara-cara melakukan publikasi ilmiah dalam menciptakan dan menambah khazanah ilmu pengetahuan. Melihat dampaknya yang begitu besar, masih terdapat pandangan di mana disrupsi digital merupakan sebuah ancaman ketimbang dianggap sebagai sebuah peluang bagi perguruan tinggi. Kenyataan yang ada, masih banyak perguruan tinggi yang minim dalam memfasilitasi proses utama menuju digitalisasi. Akses dan bandwith internet perguruan tinggi belum sesuai dengan rasio jumlah mahasiswa, publikasi hasil penelitian dan pengabdian kepada masyarakat belum secara digital, belum menerapkan jurnal online, serta masih kurangnya kehandalan website dalam memfasilitasi akses informasi ke luar dan ke dalam perguruan tinggi. Ira (2018) dalam website Ditjen Sumber Daya Iptek Dikti mengungkap, motivasi menulis dan knowledge sharing melalui media digital masih dirasa kurang bahkan dapat dikatakan sangat rendah (http://sumberdaya.ristekdikti.go.id/index.php/2018/02/23/produktivitasprofesor-dievaluasi-pada-2019), serta masih terdapat individu-individu dalam perguruan tinggi yang belum sepenuhnya menguasai kompetensi literasi digital. Adaptasi perguruan tinggi yang kurang dalam menyikapi perkembangan teknologi digital berimbas pada kurangnya fungsi perguruan tinggi untuk memenuhi kebutuhan, mengatasi permasalahan-permasalahan sosial, serta proses pendidikan yang dilakukan tidak secara tepat dan cepat tertuju untuk kesejahteraan masyarakat.

Minyakapi era modern dan digitalisasi, perguruan tinggi diharuskan terus berbenah, bergerak dinamis seiring dengan perkembangan masyarakat. Perguruan tinggi wajib melaksanakan seluruh dimensi yang melekat. Dimensi keilmuan perguruan tinggi (dalam menciptakan knowledge) terangkum dalam sebuah kebebasan akademik, yang menjamin kebebasan seluruh sivitas akademika untuk mendalami, mengembangkan, dan mencari ilmu pengetahuan serta kebenaran secara konsisten, profesional, dan bertanggungjawab, melalui analisis dan cara-cara yang ilmiah. Prinsip kebebasan akademik berlaku pada core process perguruan tinggi, melebur dalam pelaksanaan Tridharma Perguruan Tinggi yang meliputi pendidikan dan pembelajaran, penelitian, serta pengabdian kepada masyarakat. Dengan kebebasan akademik, SDM intelektual perguruan tinggi menjalankan fungsi, visi, dan misi perguruan tinggi, dengan tidak adanya intervensi dari kekuasaan luar. Publikasi karya-karya ilmiah, seminar hasil penelitian, mimbar akademik menyampaikan gagasan dan temuan-temuan ilmiah, 
pengabdian untuk mengatasi berbagai permasalahan masyarakat dengan disiplin dan keilmuan yang dimiliki, serta hasil karya seluruh civitas akademika merupakan urgensi mengapa kebebasan akademik sangat fundamental dalam masyarakat perguruan tinggi.

Kebebasan akademik syarat akan masyarakat ilmiah, melekat secara kuat etika dan moral dalam mengimplementasikan kebebasan itu sendiri. Namun demikian, berbagai kemudahan akses informasi dampak kemajuan teknologi membawa permasalahan tersendiri khususnya dalam membentuk degradasi kebebasan akademik perguruan tinggi. Jerome Wirawan dalam BBC News Indonesia (2017) menuliskan plagiat dalam menghasilkan karya ilmiah dan pelanggaran terhadap hak kekayaan intelektual banyak terjadi pada perguruan tinggi (http://www.bbc.com/indonesia/indonesia-41262922). Penyimpangan kebebasan akademik marak terjadi, kebebasan akademik dijadikan dalil untuk menciptakan protes dan kritik-kritik sosial melalui media digital, yang sesungguhnya tindakan tersebut diragukan dan tidak dapat dibenarkan secara ilmiah.

Perkembangan teknologi digital khususnya internet, juga berakibat pada terciptanya berbagai peraturan dan kebijakan yang mengatur pelaksanaan Tridarma perguruan tinggi khususnya dalam menciptakan knowledge baru, karya-karya ilmiah, serta mengatur proses publikasi produk-produk ilmiah perguruan tinggi agar mampu berdaya guna dan sampai kepada masyarakat yang membutuhkan. Disrupsi digital selaras dengan disrupsi inovasi membutuhkan adanya perubahan dari cara-cara lama dalam mengimplementasikan kebebasan akademik menuju cara baru dengan langkah-langkah sistematis dan ilmiah yang sejalan dengan perkembangan masyarakat, peraturan dan undang-undang yang berlaku, serta sejalan dengan perkembangan teknologi digital masyarakat sekarang ini. Teknologi digital berperan penting dalam lingkup kebebasan akademik masa sekarang. Secara bebas mencari pengetahuan, mengembangkan pengetahuan, mengemukakan karya dan publikasi ilmiah, dan menyebarkan pengetahuan untuk kesejahteraan masyarakat yang tentunya dengan meninggalkan cara tradisonal menciptakan langkah dan inovasi baru melalui pemanfaatan teknologi digital.

Bagaimanakah kebebasan akademik di era disrupsi digital menjadi permasalahan tersendiri dalam kajian ini. Kajian ini berfokus pada implementasi kebebasan akademik di era digital, berbagai inovasi dan langkah nyata menciptakan inovasi dan business process baru dalam pelaksanaan Tridharma Perguruan Tinggi dalam naungan kebebasan akademik. Hasil kajian diharapkan memberikan deskripsi dan gambaran kebebasan akademik yang sebenarnya di era digital.

Disrupsi Digital

Disrupsi digital mengacu pada kecepatan dan besarnya kemajuan teknologi yang mengganggu cara-cara yang telah ditetapkan untuk 
mnciptakan nilai, baik dalam pemasaran, interaksi sosial, serta pemikiran, dan pemahaman individu (Patra, 2017: 1). Teknologi digital membawa keadaan disrupsi berbagai sektor masyarakat. Perkembangan teknologi mewajibkan restrukturisasi berbagai jenis business process, manajemen lembaga, organisasi, dan institusi agar sejalan dengan perkembangan teknologi itu sendiri. Disrupsi digital terjadi pada berbagai aspek dan tingkatan, mulai dari individu, praktik kerja, praktik bisnis, struktur industri, dan sosial masyarakat. Disrupsi dalam kaitannya dengan teknologi digital, menjadikan cara, model, dan business process lama menjadi tidak lagi relevan di masyarakat. Perkembangan masyarakat modern dengan adopsi teknologi yang cukup tinggi memaksa terciptanya berbagai inovasi manajemen dan kebijakan untuk segera menciptakan dan menjalankan langkah-langkah, model, dan business process yang inovatif dengan pendekatan yang berbeda agar mampu bertahan masa sekarang dan yang akan datang (Christensen, Clayton M. et. al., 2015: 44-53). Inovasi yang diciptakan harus mampu memudahkan dan meningkatkan pelayanan dan juga memberikan efisiensi yang tinggi. Peningkatan pelayanan dengan berbagai dukungan dan pemanfaatan teknologi, menjadikan keadaan disrupsi tidak sekadar ancaman tetapi menimbulkan peluang tanpa harus mengubah arah dan core business process. Dari beberapa pengertian dan penjelasan di atas, disrupsi digital merupakan sebuah keadaan disrupsi (ancaman atau gangguan) akibat perkembangan teknologi digital yang begitu pesat, tentunya mengharuskan adanya perubahan, adaptasi, dan inovasi dari cara-cara yang telah ditetapkan untuk menciptakan nilai, baik dalam pemasaran, interaksi sosial, serta pemikiran dan pemahaman individu. Disrupsi digital membawa pada keadaan yang menjadikan cara, model, dan business process lama menjadi tidak lagi relevan di masyarakat, untuk itu sangat dibutuhkan adanya sebuah inovasi agar dapat bertahan menjalankan core business masa sekarang dan yang akan datang.

\section{Kebebasan Akademik}

Dalam Undang-undang Republik Indonesia No. 12 Tahun 2012 Tentang Pendidikan Tinggi, kebebasan akademik merupakan kebebasan seluruh sivitas akademika dalam pendidikan tinggi untuk mendalami dan mengembangkan ilmu pengetahuan dan teknologi secara bertanggung jawab melalui pelaksanaan Tridharma Perguruan Tinggi. Kebebasan akademik merupakan kebebasan yang melekat pada civitas akademik sebagai masyarakat akademik yang terdiri dari dosen dan mahasiswa. Dosen adalah pendidik profesional dan ilmuwan dengan tugas utama mentransformasikan, mengembangkan, dan menyebarluaskan ilmu pengetahuan dan teknologi melalui pendidikan, penelitian, dan pengabdian kepada masyarakat. Sedangkan mahasiswa adalah peserta didik pada jenjang pendidikan tinggi. Pada intinya, kebebasan akademik adalah kebebasan mengejar kebenaran dengan cara yang konsisten dan profesional melalui standar penyelidikan 
(Downs, 2009: 4). Kebebesan akademik dilakukan dengan tanggung jawab juga meliputi etika dan moral yang melekat pada setiap individu bagian dari masyarakat akademik. Penciptaan knowledge dan pengajaran pengetahuan dilakukan dengan analisis dan cara-cara ilmiah, sistematis, serta mampu dipertanggungjawabkan.

Undang-undang Republik Indonesia No.12 Tahun 2012 Tentang Pendidikan Tinggi juga menjelaskan pelaksanaan kebebasan akademik tidak terlepas dari mimbar akademik dan otonomi keilmuan. Mimbar akademik merupakan otoritas dan wibawa ilmiah untuk menyatakan secara terbuka dan bertanggung jawab mengenai sesuatu yang berkenaan dengan rumpun ilmu dan cabang ilmunya. Sedangkan otonomi keilmuan merupakan otonomi sivitas akademika pada suatu cabang ilmu pengetahuan dan/atau teknologi dalam menemukan, mengembangkan, mengungkapkan, dan/atau mempertahankan kebenaran ilmiah menurut kaidah, metode keilmuan, dan budaya akademik. Dapat disimpulkan, kebebasan akademik merupakan sebuah kebebasan seluruh sivitas akademika dalam pendidikan tinggi meliputi dosen dan mahasiswa untuk menciptakan, mengajar, mendalami, dan mengembangkan ilmu pengetahuan secara bertanggung jawab dan profesional melalui pelaksanaan pendidikan/pembelajaran, penelitian, dan pengabdian kepada masyarakat. Dalam pelaksanaan dan implementasi kebebasan akademik tidak terlepas dari mimbar akademik dan otonomi keilmuan.

\section{B. Metodologi}

Kajian ini merupakan kajian kepustakaan dengan menggunakan teknis analisis sintesis wacana. Analisis terdiri pendahuluan, lanjutan, dan akhir, dengan mempertimbangkan unsur teks, konteks, dan wacana (zed, 2008: 71, 76-77). Sintesis yang dilakukan merupakan kelanjutan dari proses analisis dalam upaya merekonstruksi teks dan konteks. Sintesis dilakukan dengan menggunakan perbandingan isu-isu dan fakta dalam rangka menjelaskan implementasi kebebasan akademik di era disrupsi digital. Teks dalam kajian tidak dipahami semata-mata sebagai studi bahasa dan tidak sekadar kata-kata yang tercetak atau tertulis. Teks dalam kajian berkaitan dengan kebebasan akademik dan era disrupsi digital. Penelitian terdahulu, kasus, dan data yang didapatkan dari internet juga menjadi unsur penting dalam memenuhi subtansi teks dalam kajian.

Konteks menggambarkan relasi antarteks dengan memasukkan semua situasi yang terkait pula dengan situasi di luar teks, digunakan untuk mencapai tujuan berkaitan dengan implementasi kebebasan akademik di era disrupsi digital. Sedangkan wacana merupakan upaya mengungkapkan maksud serta pemahaman teks dan konteks, baik yang tersirat dari berbagai teks maupun yang tergambar jelas pada teks kebebasan akademik dan era disrupsi digital. Sintesis pendahuluan dilakukan dengan upaya menggabungkan secara konsisten antara analisis dan sintesis, meliputi fakta, 
gagasan, konsep, pandangan, teori, dan metode. Sintesis pendahuluan berupaya menata kembali analisis dalam rangka menjelaskan komponen kebebasan akademik di era disrupsi digital.

\section{Hasil dan Pembahasan}

1. Konteks Kebebasan Akademik dan Disrupsi Digital

Teks kebebasan akademik berkaitan dengan konsep mendalami, mengembangkan, dan menyebarkan ilmu pengetahuan melalui pelaksanaan Tridharma Perguruan Tinggi secara ilmiah, profesional, dan bertanggung jawab yang di dalamnya tidak terpisahkan dari etika dan moralitas. Teks kebebasan akademik diperluas dengan menghubungkan fungsi dan berbagai situasi di luar konsep membentuk sebuah konteks kebebasan akademik.

Tabel 1. Konteks Kebebasan Akademik dan Disrupsi Digital

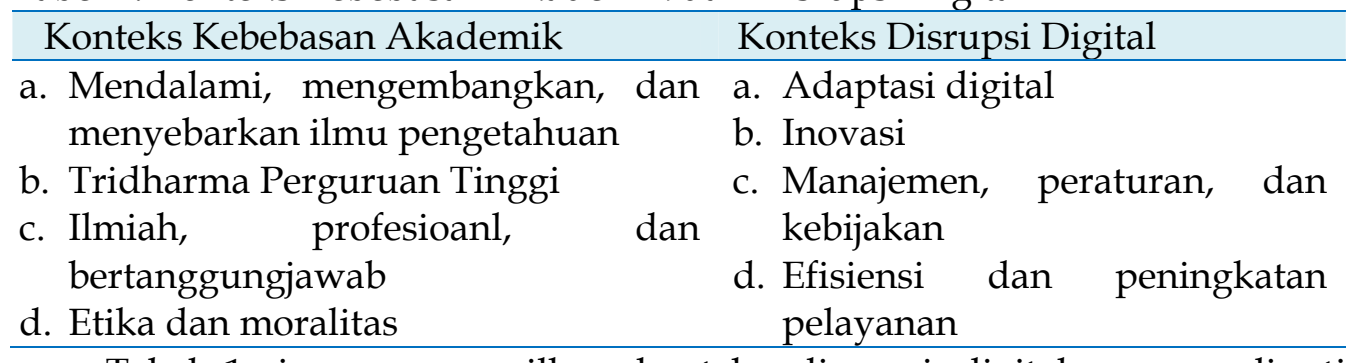

Tabel 1. juga menampilkan konteks disrupsi digital yang meliputi adaptasi, inovasi, penciptaan manajemen, peraturan, dan kebijakan, serta efisiensi dan peningkatan pelayanan. Konteks disrupsi digital terbentuk dari sebuah konsep teks yang melihat perkembangan dan kemajuan teknologi digital sebagai sebuah keadaan yang harus disikapi dengan inovasi, restrukturisasi proses bisnis, manajemen, dan kebijakan guna memberikan value yang berimbas pada efisiensi efektivitas, dan peningkatan pelayanan perguruan tinggi.

2. Wacana Kebebasan Akademik dan Disrupsi Digital

Wacana berusaha memahami teks dan konteks kebebasan akademik dan disrupsi digital. Wacana juga merupakan proses sintesis teks dan konteks. Tabel 2 menampilkan wacana kebebasan akademik dan disrupsi digital.

Tabel 2. Wacana Kebebasan Akademik dan Disrupsi Digital

\begin{tabular}{lll} 
Konteks Kebebasan Akademik & Konteks Disrupsi Digital \\
\hline $\begin{array}{l}\text { a. Mendalami, mengembangkan, dan } \\
\text { menyebarkan ilmu pengetahuan }\end{array}$ & $\begin{array}{l}\text { a. Adaptasi (cara, model, strategi) } \\
\text { b. Inovasi (produk dan hasil) }\end{array}$ \\
$\begin{array}{ll}\text { b. Pelaksanaan Tridharma Perguruan } \\
\text { Tinggi }\end{array}$ & $\begin{array}{l}\text { c. Manajemen, peraturan, dan } \\
\text { kebijakan }\end{array}$ \\
$\begin{array}{lll}\text { c. Ilmiah, profesional, dan } \\
\text { bertanggungjawab }\end{array}$ & $\begin{array}{l}\text { d. Efisiensi, efektivitas, dan } \\
\text { peningkatan pelayanan }\end{array}$ \\
d. Etika dan moralitas & &
\end{tabular}


Wacana Kebebasan Akademik dan Disrupsi Digital

a. Mendalami, mengembangkan, dan menyebarkan knowledge dengan mengadopsi teknologi

b. Menciptakan inovasi dalam pelaksanaan Tridharma Perguruan Tinggi

c. Mempertahankan nilai-nilai ilmiah, profesional, dan bertanggungjawab

d. Menjunjung tinggi etika dan moralitas

e. Komitmen dan pelaksanaan terhadap manajemen, peraturan, dan kebijakan yang telah ditetapkan

f. Efisiensi, efektivitas, dan meningkatkan pelayanan perguruan tinggi

3. Sintesis Kebebasan Akademik dan Disrupsi Digital

Proses sintesis terhadap teks, konteks, dan wacana memberikan analisis penggabungan konsep yang mengarah pada implementasi kebebasan akademik di era disrupsi digital. Memberikan gambaran bagaimana kebebasan akademik tetap tertanam dan dijalankan oleh seluruh sivitas akademika di era disrupsi digital yang syarat akan inovasi.

Sintesis kebebasan akademik di era disrupsi digital terfokus pada beberapa langkah, yaitu:

a. Mengadopsi teknologi digital dalam mendalami, mengembangkan, dan menyebarkan knowledge;

b. Menciptakan berbagai inovasi baru dalam pelaksanaan Tridharma Perguruan Tinggi;

c. Tetap mempertahankan nilai-nilai ilmiah, profesional, dan bertanggungjawab;

d. Menjunjung tinggi etika dan moralitas;

e. Komitmen dan melaksanakan manajemen, peraturan, dan kebijakan yang telah ditetapakan;

f. Menciptakan efisiensi, efektivitas dan peningkatan pelayanan perguruan tinggi.

Bagaimanakah kebebasan akademik di era disrupsi digital dapat terjawab dan terimplementasi melalui beberapa langkah sebagai berikut:

1. Adopsi teknologi digital dalam mendalami, mengembangkan, dan meyebarkan knowledge.

Kebebasan akademik menjadi rule masyarakat perguruan tinggi dalam menghasilkan pemikiran, berbagai karya kreatif dan produktif dengan nilainilai ilmiah. Mendalami, mengembangkan, dan menyebarkan knowledge baru merupakan hal yang wajib agar perguruan tinggi dengan dimensi sosial yang melekat mampu meningkatkan kesejahteraan masyarakat. Perguruan tinggi menciptakan para mahasiswa sebagai insan-insan intelektual untuk mengambil tanggung jawab ikut memecahkan permasalahan masyarakat. Masyarakat sebagai target utama jasa pendidikan yang dilakukan perguruan tinggi. Oleh sebab itu, agar dapat diterima dan mampu sejalan dengan perkembangan masyarakat itu sendiri, dibutuhkan segala upaya dan daya 
untuk beradaptasi dengan perkembangan masyarakat yang cepat dan bergerak dinamis.

Kemajuan teknologi dan informasi membawa pada terciptanya budaya konsumtif yang tinggi terhadap produk dan aplikasi teknologi. Adopsi teknologi menjadi langkah utama dalam melakukan perubahan manajemen perguruan tinggi. Di era digital seperti sekarang, perguruan tinggi dengan segala sumber daya yang ada harus secara langsung menggunakan, menerapkan, dan memanfaatkan teknologi digital dalam mendalami, mengembangkan, dan menyebarkan knowledge. Internet dengan berbagai aplikasi dan produk yang mengikuti menjadi media dan wadah dalam memenuhi berbagai aspek pengetahuan, mengembangkan kompetensi, dan berbagi (sharing) knowledge.

Adopsi teknologi menjadi bentuk adaptasi perguruan tinggi dengan segala komponen dan sumber daya melalui cara-cara, model, dan strategi yang tepat di era digital. Website, blog, search engine, media dan jejaring sosial menjadi alat untuk terus mengejar pengetahuan dan pengalaman dengan perlindungan dan otonomi penuh yang diberikan oleh kebebasan akademik perguruan tinggi. Dosen harus terus berusaha meningkatkan kompetensi keilmuan dan penelitian secara maksimal dengan dukungan teknologi. Dalam proses pembelajaran pada perguruan tinggi, teknologi digital tidak lagi sekadar support melainkan suatu keharusan untuk terintegrasi dalam pembelajaran, dengan demikian akan tercipta sebuah kompetensi bagi para mahasiswa sebagai syarat untuk dapat diterima dalam masyarakat digital dan modernisasi. Pada perguruan tinggi, teknologi digital membawa perubahan sistem tertutup ke arah sistem terbuka yang menciptakan konektivitas, komunitas, komunikasi, dan kolaborasi, seluruh komponen perguruan tinggi mulai dari administrasi, fasilitas dan sarana-prasarana, serta data dan informasi yang menghasilkan peningkatan value perguruan tinggi dalam menjalankan jasa pendidikan yang dilakukan.

2. Menciptakan berbagai inovasi baru dalam pelaksanaan Tridharma Perguruan Tinggi

Kebebasan akademik berkaitan erat dengan pelaksanaan Tridharma Perguruan Tinggi. Berbagai kegiatan perguruan tinggi, seperti pembelajaran, penelitian, dan pengabdian kepada masyarakat sebagai wujud proses ilmiah dilindungi dalam kebebasan ilmiah. Kebebasan ilmiah memberikan jaminan bagi sivitas akademika perguruan tinggi untuk menghasilkan dan menciptakan temuan-temuan, produk, dan hasil ilmiah yang objektif yang dapat digunakan untuk kesejahteraan dan pembangunan masyarakat. Dengan tidak adanya kebebasan akademik, akan sangat sulit bagi dosen dan mahasiswa untuk menghasilkan inovasi dan karya-karya ilmiah yang objektif. Negara-negara maju, yang selama ini menjadi pusat perkembangan ilmu pengetahuan dan teknologi, menghadapi perubahan yang melaju deras tak tertahankan dan tidak gampang diatasi dengan instrumen yang ada hari ini (Barber, et. al., 2013). Kaitannya dengan sistem pendidikan tinggi di Indonesia, 
era disrupsi menjadikan sistem dan proses bisnis lama menjadi usang dan tidak lagi relevan untuk masyarakat sekarang. Dibutuhkan sebuah inovasi proses, produk, dan hasil jasa pendidikan yang dilakukan agar menjawab tantangan perkembangan zaman.

Teknologi digital telah mengubah tatanan masyarakat, juga dalam pola interaksi dan sosial. Dalam menghadapi disrupsi, dengan wewenang penuh melalui kebebasan akademik, perguruan tinggi, dosen, dan mahasiswa memungkinkan melakukan perubahan cara, pendekatan, strategi, dan metode pembelajaran. Metode pembelajaran dengan pendekatan teknologi berbasis digital dan perkuliahan online dapat diberikan, untuk dapat menjawab tantangan mengatasi batas ruang dan waktu melewati pola lama pembelajaran yang hanya terjadi di dalam kelas. Diharapkan dengan berbagai proses perubahan yang meliputi proses bisnis utama dalam perguruan tinggi menciptakan daya kompetitif yang tinggi bagi para mahasiswa dan lulusan. Dengan alasan demikian, pengembangan kurikulum dapat dilakukan sebagai antisipasi dinamika masyarakat yang berkelanjutan.

Pemanfaatan teknologi kian menjadi kebutuhan penting, tidak hanya dalam pembelajaran tetapi meliputi penelitian dan pengabdian kepada masyarakat. Perguruan tinggi mempunyai kebutuhan besar dalam pelaksanaan dan menghasilkan penelitian. Penelitian dilakukan untuk pengembangan ilmu pengetahuan dan isi pembelajaran yang terintegrasi dengan pembelajaran digital dan kompetensi global. Hasil-hasil penelitian harus menjadi sumber dan berbentuk inovasi. Publikasi ilmiah, buku, alat, produk dipatenkan, dan perusahaan start-up merupakan berbagai bentuk hasil penelitian yang membawa masyarakat untuk terus maju dan berkembang. Dengan demikian, penelitian pada perguruan tinggi tidak hanya untuk memenuhi tuntutan administrasi pelaporan Beban Kerja Dosen (BKD), kenaikan jabatan fungsional, dan akreditasi, atau hanya tersimpan pada perpustakaan perguruan tinggi.

Inovasi lain perguruan tinggi di era disrupsi dapat dilakukan melalui pendekatan dalam pengabdian kepada masyarakat. Pengabdian kepada masyarakat dapat dilakukan dengan lebih bercorak multidisiplin dan transdisiplin. Globalisasi dan kehidupan masyarakat modern ditandai dengan arus perubahan yang sangat cepat, bahkan disruptif, dalam segala bidang. Kemajuan teknologi digital membawa pada konektivitas keilmuan, kehidupan sosial, budaya, ekonomi, dan agama dengan ketidakpastian dan kompleksitas permasalahan yang tinggi. Kompleksitas permasalahan yang melekat kuat dalam masyarakat tidak dapat lagi diselesaikan hanya dengan pendekatan satu disiplin keilmuan.

3. Nilai-nilai ilmiah, profesional, dan bertanggungjawab

Teknologi digital dan internet berdampak pada keterbukaan akses informasi dan komunikasi ditandai dengan dapat diaksesnya berbagai informasi kapan saja dan di mana saja. Sumber-sumber informasi terbuka lebar, kebutuhan informasi perguruan tinggi dapat dengan mudah terpenuhi 
melalui pemanfaatan internet. Aplikasi seperti webiste, blog, search engine, ebook, e-library, e-journal, instant messaging, surat kabar online, media dan jejaring sosial dapat dengan mudah diakses dan memberikan kemudahan dalam memenuhi kebutuhan informasi sivitas akademika perguruan tinggi. Kendati demikian, menjadi penting adalah bagaimana karya-karya ilmiah sebagai sebuah produk perguruan tinggi yang diciptakan kaum intelektual kampus dihasilkan melalui cara-cara yang ilmiah, secara profesional dan sistematis, dengan sumber-sumber informasi yang kredibel, serta mampu dipertanggungjawabkan.

Fondasi ilmiah tetap menjadi pijakan seluruh sivitas akademika perguruan tinggi sebagai masyarakat ilmiah, melekat padanya sebuah kebebasan akademik yang tidak mendapat intervensi dan tekanan dari kekuasaan dari luar perguruan tinggi. Dengan demikian perguruan tinggi telah menciptakan budaya internal yang berdampak pada terciptanya lulusan dengan kompetensi dan kemampuan ilmiah untuk mengisi kebutuhan masyarakat yang terus berkembang. Nilai-nilai ilmiah, profesional, dan bertanggung jawab berpangkal pada keaslian dan kejujuran. Kejujuran untuk menghasilkan dan mengemukakan kebenaran ilmiah harus tertanam baik pada dosen dan mahasiswa. Jika demikian, tidak adalagi perilaku-perilaku tercela yang mencemarkan kebebasan akademik seperti plagiarisme yang marak terjadi di era digital seperti sekarang ini.

4. Menjunjung tinggi etika dan moralitas

Perkembangan digital berakibat pada terciptanya berbagai strategi, perubahan manajemen, dan kebijakan. Tantangan revolusi industri 4.0 harus direspon secara tepat dan cepat oleh lembaga, organisasi, institusi, dan kementerian di Indonesia. Era industri 4.0 mewajibkan teknologi informasi dan digital terintegrasi dalam berbagai aspek masyarakat, tidak terkecuali dalam dunia pendidikan. Menjadi penting adalah bagaimana penggunaan dan pemanfaatan teknologi digital tetap berada pada ranah yang baik dan benar, benar dalam konteks individu, benar dalam pelaksanaan kebijakan dan peraturan, serta kebenaran dalam masyarakat itu sendiri. Perkembangan dan teknologi digital mendisrupsi aspek masyarakat, termasuk aktivitas dalam keseharian. Yang dibutuhkan adalah bagaimana mempertahankan nilai-nilai sosial kemanusiaan melalui perilaku penggunaan teknologi secara benar dengan menjunjung tinggi cara-cara, nilai ilmiah, dan academic value. Konteks kebebasan akademik dalam pemanfaatan media digital yaitu penggunaan dan pemanfaatan dengan mempertahankan nilai-nilai ilmiah, sikap, beserta etika dan moral yang melekat.

Kritik terhadap sebuah kebijakan dan jalannya pemerintahan yang marak pada media dan jejaring sosial di era digital seperti sekarang ini menyimpang jauh dari implementasi kebebasan akademik perguruan tinggi. Dengan dalil kebebasan akademik dan otoritas ilmiah kerap kali terjadi berbagai perilaku masyarakat kampus secara individu dan berkelompok yang bertentangan dan mengancam tatanan stabilitas sosial masyarakat. Perlu 
dipahami secara mendalam, kebebasan akademik berkaitan erat dengan fungsi perguruan tinggi memenuhi kebutuhan masyarakat akan pendidikan tinggi masyarakat dengan nilai-nilai ilmiah. Demonstrasi, kritik keras melalui media digital, dan mengemukakan pendapat secara terbuka pada jejaring sosial tidak menyentuh utuh pada kebebasan akademik, perlu dibedakan antara kebebasan akademik dengan kebebasan umum sebagai warga negara.

Etika dan moral menjadi batas-batas mencari pengetahuan, menciptakan karya akademik, dan penyampaian karya ilmiah yang merupakan produk kebebasan akademik. Kenyataan yang ada, perkembangan teknologi informasi dan digital tidak selalu ditempatkan pada ranah positif. Berbagai perilaku negatif pemanfaatan teknologi dalam pembelajaran sporadis bermunculan. Plagiat, budaya copy dan paste yang buruk, pelanggaran hak atas kekayaan intelektual, pencurian data dan informasi, akses terhadap konten ilegal, serta perilaku bermedia dan berjejaring sosial yang tidak benar menjadi permasalahan yang kerap kali muncul dalam proses pembelajaran di era modern. Kejujuran dan penghargaan terhadap orang lain atas karya-karya yang dihasilkan harus tertanam di era digital dengan kemudahan akses informasi yang diberikan. Penerapan etika juga dapat terlihat melalui penyebutan sumber dan pengutipan pendapat maupun tulisan yang berasal dari karya ilmiah orang lain.

Perkembangan dan kemajuan masyarakat di era digital tidak sebatas pada percepatan karya yang dihasilkan, tetapi juga menyentuh pada tatanan dan kehidupan sosial. Tatanan sosial mengharuskan setiap masyarakat berkesadaran untuk mengarahkan aktivitas dan segala sesuatunya sesuai dengan etika, moral, dan hukum yang berlaku. Keharusan yang ada adalah bagaimana kemudahan-kemudahan sebagai dampak positif perkembangan teknologi harus tetap sejalan dengan perilaku dan penggunaan yang baik dan benar secara sosial. Etika dan moral harus tetap diutamakan dalam penggunaan teknologi. Etika dan moral menjadi penting dalam pembelajaran, penelitian, dan pengabdian kepada masyarakat agar tidak berdampak pada degradasi tujuan pendidikan itu sendiri. Kaitannya dengan penggunaan teknologi dan komputer di era digital, isu utama etika komputer dan keamanan komputer (security) harus dipahami secara mendalam oleh masyarakat pengguna.

5. Pelaksanakan manajemen, peraturan, dan kebijakan yang telah ditetapkan

Berbagai manajemen, peraturan, dan kebijakan perlu dibuat sebagai langkah konkret dan respon terhadap perkembangan masyarakat dan teknologi digital yang semakin mendisrupsi. Undang-undang, peraturan menteri, dan peraturan pemerintah yang telah ditetapkan perlu secara konsisten dilaksanakan oleh seluruh sumber daya perguruan tinggi untuk menghadapi tuntutan perkembangan masyarakat, globalisasi, dan modernisasi. Dalam hal peningkatan kinerja dosen, perlu dilakukan evaluasi penyelenggaraan Tridharma Perguruan Tinggi khususnya di bidang penelitian dalam rangka meningkatkan jumlah dan mutu penelitian dosen. 
Seperti tertuang dalam Peraturan Menteri Riset, Teknologi, dan Pendidikan Tinggi Republik Indonesia No.20 Tahun 2017, tentang Pemberian Tunjangan Profesi Dosen dan Tunjangan Kehormatan Profesor, secara mendasar sangat erat kaitannya dengan implementasi kebebasan akademik dalam menghasilkan, meningkatkan kualitas dan kuantitas penelitian, serta publikasi ilmiah.

Teknologi digital terintegrasi dalam berbagai manajemen, peraturan, dan kebijakan yang telah ditetapkan. Pemerintah melalui kementerian terkait terus meningkatkan hasil-hasil penelitian untuk dapat dipublikasikan di tingkat global (internasional). Digitalisasi mengharuskan pelaksanaan berbagai aturan dan kebijakan yang telah dirumuskan dalam menghadapi tantangan dan perkembangan masyarakat yang semakin digital. Layanan informasi publik, sistem penghimpun data pendidikan tinggi terintegrasi (seperti PDDikti), SINTA (Science and Technology Index), dan ARJUNA (Akreditasi Jurnal Nasional) merupakan bentuk-bentuk respon dan inovasi digital dalam menghadapai era disrupsi yang secara konsisten harus dapat diterima dan dijalankan oleh seluruh sember daya pendidikan khususnya di perguruan tinggi.

6. Efisiensi, efektivitas, dan peningkatan pelayanan perguruan tinggi

Kebijakan dan perubahan manajemen akan berlangsung dengan baik melalui pengelolaan yang baik. Pemanfaatan dan penggunaan teknologi mengarah pada efisiensi dan efektivitas proses pembelajaran, penelitian, dan pengabdian kepada masyarakat yang dilakukan perguruan tinggi. Inovasi yang dihasilkan dapat digunakan untuk mendukung pelayanan perguruan tinggi. Pada akhirnya menciptakan sebuah value dari jasa pendidikan yang dilakukan. Kebebasan akademik dan otonomi keilmuan pada dimensi korporasi/institusi perguruan tinggi melalui berbagai perubahan yang dilakukan mengikuti tuntutan perkembangan zaman membawa pada peningkatan akuntabilitas dan kualitas di tingkat negara maupun internasional. Dengan inovasi sebagai tindak lanjut dari sebuah disrupsi, berbagai produk dan profesi hasil pendidikan sebuah perguruan tinggi tidak akan pernah hilang relevansinya terhadap sebuah peradaban masyarakat sekarang dan yang akan datang.

\section{Simpulan}

Hasil kajian memberikan penggambaran implementasi kebebasan akademik perguruan tinggi di era disrupsi digital. Kebebasan akademik di era disrupsi digital terfokus pada: 1) adopsi teknologi digital dalam mendalami, mengembangkan, dan menyebarkan knowledge; 2) menciptakan berbagai inovasi baru dalam pelaksanaan Tridharma Perguruan Tinggi; 3) tetap mempertahankan nilai-nilai ilmiah, profesional, dan bertanggungjawab; 4) menjunjung tinggi etika dan moralitas; 5) komitmen dalam melaksanakan 
manajemen, peraturan, dan kebijakan yang telah ditetapkan; dan 6) menciptakan efisiensi, efektivitas, dan peningkatan pelayanan perguruan tinggi.

\section{Daftar Pustaka}

Barber, M., K. Donnelly and S. Rizvi. 2013. An avalanche is coming: Higher education and the revolution ahead. Paper published by the Institute for Public Policy Research. London, UK.

BBC Indonesia. 2017. Plagiarisme di 'puluhan universitas' sudah mengarah ke jual-beli ijazah. http://www.bbc.com/indonesia/indonesia-41262922 (Diakses 13 Maret 2018).

Christensen, Clayton. M, et. al., 2015. Disruptive Innovation, what is disruptive innovation?. A version of this article appeared in the December 2015 issue (pp.44-53) of Harvard Business Review.

Ditjen Sumber Daya Iptek Dikti. 2018. Produktivitas Profesor dievaluasi pada 2019.

http://sumberdaya.ristekdikti.go.id/index.php/2018/02/23/produktiv itas-profesor-dievaluasi-pada-2019 (diakses 27 Maret 2018).

Ditjen Sumber Daya Iptek Dikti. 2018. Menristekdikti Dorong Dosen Tingkatkan Publikasi Ilmiah. http://sumberdaya.ristekdikti.go.id/ index.php/2017/03/30/menristekdikti-dorong-dosen-tingkatkanpublikasi-ilmiah (diakses 22 Maret 2018).

Donald A. Downs. 2009. Academic Freedom: what it is, what it isn't, and how to tell the difference. John W. Pope Center for Higher Education Policy. popecenter.org. ISSN 1935-3510.

Kenney, Martin. Et. al., 2014. The Digital Disruption and its Societal Impacts. Published online 10 Februari 2015. Springerlink.com.

Nihar K. Patra. 2017. Digital Disruption And Electronic Resource Management In Libraries. United States: Chandos Publishing Is An Imprint Of Elsevier.

Oey-Gardiner, Mayling, dkk. 2017. Era Disrupsi: Peluang dan Tantangan Pendidikan Tinggi Indonesia. Jakarta: Akademi Ilmu Pengetahuan Indonesia.

Peraturan Menteri Riset, Teknologi, dan Pendidikan Tinggi Republik Indonesia Nomor 61 Tahun 2016, Tentang Pangkalan Data Pendidikan Tinggi.

Peraturan Menteri Riset, Teknologi, dan Pendidikan Tinggi Republik Indonesia Nomor 75 Tahun 2016 Tentang Layanan Informasi Publik di Lingkungan Kementerian Riset, Teknologi, dan Pendidikan Tinggi.

Peraturan Menteri Riset, Teknologi, dan Pendidikan Tinggi Republik Indonesia No.20 Tahun 2017, tentang Pemberian Tunjangan Profesi Dosen dan Tunjangan Kehormatan Profesor. 
R. Alan, Electronic resource management: transition from in-house to inhouse/ vendor approach, Serials Librarian 47 (4) (2005) 17_25.

Sutapa, Mada. 2010. Sebuah Refleksi kebebasan Akademik dalam Masyarakat Ilmiah Perguruan Tinggi. Jurnal Manajemen Pendidikan, No.02, Th VI/Oktober/2010, Jurusan Administrasi Pendidikan, Fakultas Ilmu Pendidikan, Universitas Negeri Yogyakarta.

T. Sadeh, M. Ellingsen. Electronic resource management systems: the need and the realization, New Library World 106 (5/6) (2005) 208_218.

Undang-Undang Republik Indonesia Nomor 12 Tahun 2012, Tentang Pendidikan Tinggi.

Zed, Mestika. 2004. Metode Penelitian Kepustakaan. Cetakan 1. Jakarta: Yayasan Obor Indonesia. 